\title{
Seasonal Uptake and Partitioning of Macronutrients in Mature 'Concord' Grape
}

\author{
Suphasuk Pradubsuk ${ }^{1}$ and Joan R. Davenport ${ }^{2}$ \\ Department of Crop and Soil Sciences, Washington State University, Irrigated Agriculture and \\ Research Extension Center, 24106 North Bunn Road, Prosser, WA 99350
}

\begin{abstract}
Additional INDEX words. calcium, magnesium, nitrogen, phosphorus, potassium, Vitis labruscana
Abstract. Understanding how grape (Vitis L.) vines store nutrients in permanent tissues, how much nutrient vines take up from the soil, and how nutrients are partitioned and redistributed throughout the plant is critical to the development of sound nutrient management practices. This study investigated the seasonal patterns of macronutrient uptake and redistribution in whole 'Concord' grape (Vitis labruscana Bailey) vines. The study was conducted in a 42year-old own-rooted 'Concord' vineyard. The site was a furrow-irrigated fine sandy loam. In 2006 and 2007 , four vines were excavated at winter pruning, budbreak, three- to four-leaf stage, bloom, veraison, harvest, and postharvest. Each vine was separated into different organs, dried, and weighed to determine biomass, and then ground and analyzed for $\mathrm{C}, \mathrm{N}, \mathrm{P}, \mathrm{K}, \mathrm{Ca}$, and $\mathrm{Mg}$. The results showed that the seasonal dynamics of nutrient contents shared a consistent pattern: translocation of nutrients from woody tissues to actively growing organs at the beginning of the season; nutrient uptake from bloom to veraison ( $P$ and $\mathrm{Mg}$ in 2006), bloom to harvest $(\mathrm{N}, \mathrm{P}, \mathrm{K}$, and $\mathrm{Ca}$ ), or veraison to harvest (P and $\mathrm{Mg}$ in 2007); and nutrient movement to woody tissues occurring after veraison until leaf fall with no further nutrient uptake. There was a very high accumulation of $\mathrm{Ca}$ in permanent structures of the vine, reflecting the high $\mathrm{Ca}$ and $\mathrm{CaCO}_{3}$ found in the soils of the region. As a result, the vines had a higher Ca content than all other nutrients throughout the growing season, which is different from findings in other growing areas.
\end{abstract}

Grape is a perennial crop in which the mineral nutrient concentration changes throughout the growing season. Not only is a portion of the vine's mineral nutrients taken up from the soil each year, the other portion is redistributed throughout the plant from woody and root tissues that function as storage organs. Most studies report that grapevines take up the majority of the $\mathrm{N}$ between bloom and veraison (Araujo and Williams, 1988; Bates et al., 2002; Hanson and Howell, 1995; Löhnertz, 1991; Mullins et al., 1992; Williams and Biscay, 1991). However, Conradie $(1980,1981,1986)$ reported substantial $N$ uptake after harvest in potted 'Chenin Blanc' grown in the South Africa. He reported that $\mathrm{N}$ uptake during the postharvest period was $27 \%$ and $37 \%$ of the total annual $\mathrm{N}$ uptake (Conradie, 1980, 1986, respectively) and provided $60 \%$ of the stored $\mathrm{N}$ for the next season (Conradie, 1992).

Potassium uptake in whole vines was examined in several studies (Conradie, 1981; Schreiner et al., 2006; Williams and Biscay, 1991). These studies showed that the bulk of $\mathrm{K}$ uptake occurred between bloom and veraison. Of the three studies, only Conradie (1981) in South Africa and Schreiner et al. (2006) in an Oregon field study examined $\mathrm{P}, \mathrm{Ca}$, and $\mathrm{Mg}$ uptake in their whole-vine studies. Their results agreed that the time of maximum $\mathrm{Ca}$ and $\mathrm{Mg}$ uptake was between bloom and veraison. However, the Oregon study on 23-year-old 'Pinot Noir' showed that P uptake occurred predominantly before bloom, while the South African study on 2-year-old 'Chenin Blanc'/99 Richter

Received for publication 24 May 2010. Accepted for publication 30 June 2010. We gratefully acknowledge the Washington State 'Concord' Grape Research Council for funding support.

We give special thanks to Robert Stevens and Markus Keller for technical consultations, as well as to Kelly Whitley, Jaimi Marden, and Kyle Bair for fieldwork support and technical assistance. We also thank the WSU-Prosser Viticulture team for vineyard maintenance.

${ }^{1}$ This article is a portion of a dissertation submitted by S.P. in fulfilling a PhD requirement.

${ }^{2}$ Corresponding author. E-mail: jdavenp@wsu.edu. vines showed peak uptake between bloom and veraison. This is probably because differences in subtle factors such as vine age, rootstock, soil texture, temperature, water management, root density, and nutrient availability, contribute to differences in grapevine performance and nutrient uptake.

'Concord' grape is the dominant cold climate American cultivar. Washington is the leading state in 'Concord' grape production, accounting for $\approx 50 \%$ of the U.S. production (U.S. Department of Agriculture, 2008). 'Concord' grape does not reach full production until about the fifth year after planting (Aegerter and Folwell, 1996). Size and seasonal duration of vegetative, reproductive, and storage sinks might vary with vine age (Borchert, 1976), cultivars (Colugnati et al., 1997), and variable weather conditions (Robinson, 2005). Direct comparison of wine grape (Vitis vinifera L.) and 'Concord' nutrient uptake and portioning may not be possible due to differences in management strategies (e.g., pruning and thinning) as well as desired crop yield levels [typically less than $8 \mathrm{Mg} \cdot \mathrm{ha}^{-1}$ for wine grape and over $20 \mathrm{Mg} \cdot \mathrm{ha}^{-1}$ for 'Concord' (U.S. Department of Agriculture, 2008)]. Whole plant sampling can be used to look at nutrient partitioning and distribution/redistribution to provide a full picture of nutrient dynamics. The present study was conducted to investigate the seasonal pattern of macronutrient uptake and redistribution in mature 'Concord' grapes.

\section{Materials and Methods}

The study was conducted in an own-rooted 'Concord' singlecurtain vineyard at the Washington State University Irrigated Agriculture Research and Extension Center (IAREC) in Prosser, WA (lat. $46^{\circ} 15^{\prime} 59^{\prime \prime} \mathrm{N}$, long. $119^{\circ} 44^{\prime} 4^{\prime \prime} \mathrm{W}$ ). Vines were planted in 1965. The site was furrow irrigated and has been managed with uniform fertilization, water, and pest management practices. The vineyard soil is Warden fine sandy loam (coarse-silty, mixed, superactive, mesic Xeric Haplocambid). Due to the great 
diversity in plant sizes in this very old vineyard, all grape plants in the 0.61-ha vineyard were measured to determine uniform sized vines for excavation. We chose vines with a 12.8- to $15.0-\mathrm{cm}$ trunk circumference at $30 \mathrm{~cm}$ above the soil surface, 87 to $99 \mathrm{~cm}$ trunk length from soil surface to cordon split, and 25 to $36 \mathrm{~cm}$ cordon length before attachment to the cordon wire for experimental units.

In 2006 and 2007 at winter pruning, budbreak, three- to fourleaf stage, bloom, veraison, harvest, and postharvest (Table 1), four vines of uniform size were sampled. The aboveground vine was removed by cutting off the trunk at ground level and at the cordon with a chainsaw. The cordon was carefully removed from the wire to retain all plant material. Fine roots were sampled by coring the soil with a hydraulic soil probe (Kaufman Metal Works, Eugene, OR) in a circular pattern around the trunk immediately after vine removal. The soil was sampled to a $1 \mathrm{~m}$ depth, was divided into $0-$ to $30-\mathrm{cm}$ and $30-$ to $100-\mathrm{cm}$ increments, stored cool, and gently rinsed over a $<2-\mathrm{mm}$ mesh screen to remove the soil from the roots. The remaining roots in the area under a single vine $(2.4 \times 2.7 \times 1 \mathrm{~m})$ were extracted from the soil by gently digging the soil away from the root mass, maintaining connectivity of the roots, and extracting the entire root ball. Each vine was separated (Fig. 1) into trunk and cordon, coarse roots (diameter $>4 \mathrm{~mm}$ ), fine roots (diameter $<4 \mathrm{~mm}$ ), canes, shoot, leaf blades, petioles, shoot tips, and clusters (including rachis and seeds).

Plant organs were dried $\left(60^{\circ} \mathrm{C}, 48 \mathrm{~h}\right)$, weighed, ground, and analyzed for nutrient elements. For large woody pieces such as the trunk, two small sections of the organ were collected. One was weighed and dried to determine dry weight. The other was pre-ground, while still moist, in a coffee mill (Krups, Millville, $\mathrm{NJ}$ ), dried, and finely ground. Total $\mathrm{C}$ and $\mathrm{N}$ were analyzed using dry combustion (Yeomans and Bremner, 1991) with an elemental analyzer (CNS 2000; LECO. St. Joseph, MI). Analysis for $\mathrm{P}, \mathrm{K}, \mathrm{Ca}$, and $\mathrm{Mg}$ was conducted by a commercial laboratory using inductively coupled plasma spectroscopy [ICP (Soltanpour et al., 1996)]. The samples were digested with nitric acid and hydrogen peroxide in a microwave oven (CEM,

Table 1. Weather condition and sampling date according to phenological development of 'Concord' grapes in 2006 and 2007 at a vineyard in Prosser, WA.

\begin{tabular}{|c|c|c|c|c|c|c|}
\hline \multirow{2}{*}{$\begin{array}{l}\text { Growth } \\
\text { stage }\end{array}$} & \multicolumn{2}{|c|}{ Sampling date } & \multicolumn{2}{|c|}{$\operatorname{GDD}\left(>10^{\circ} \mathrm{C}\right)^{z}$} & \multicolumn{2}{|c|}{ Mean temp $\left({ }^{\circ} \mathrm{C}\right)^{z}$} \\
\hline & 2006 & 2007 & 2006 & 2007 & 2006 & 2007 \\
\hline Dormant & 7 Mar. & 5 Mar. & - & - & 6.63 & 8.21 \\
\hline Budbreak & 3 Apr. & 2 Apr. & 52 & 41 & 10.79 & 10.08 \\
\hline $\begin{array}{l}\text { Three- to } \\
\text { four-leaf } \\
\text { stage }\end{array}$ & 8 May & 7 May & 172 & 177 & 15.21 & 14.99 \\
\hline \multirow[t]{2}{*}{ Bloom } & 6 June & 6 June & 278 & 246 & 18.79 & 17.43 \\
\hline & & & 430 & 466 & 23.27 & 23.54 \\
\hline Verai & 26 Aug. & 10 Aug. & 336 & 318 & 20.84 & 20.3 \\
\hline Harvest & 18 Sept. & 17 Sept. & 197 & 186 & 16.52 & 15.86 \\
\hline Postharvest & 9 Oct. & 8 Oct. & 34 & 27 & 10.25 & 8.27 \\
\hline Cumulative $^{\mathrm{y}}$ & & & 1503 & 1414 & & \\
\hline
\end{tabular}

${ }^{\mathrm{z}}$ Mean monthly temperature and total growing degree days (GDD) data were monitored by Washington State University Irrigated Agriculture Research and Extension Center using data loggers (CR-1000; Campbell Scientific, Logan, UT).

${ }^{\mathrm{y}}$ Cumulative GDD between budbreak and harvest for each year.

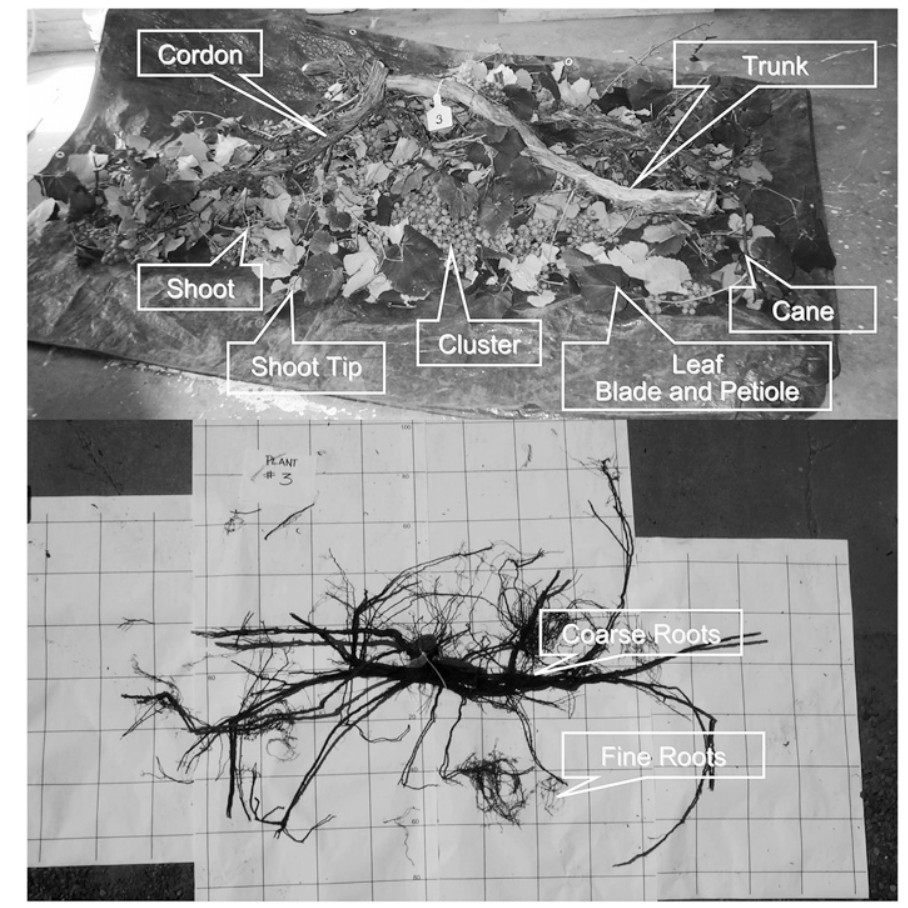

Fig. 1. A whole 'Concord' grape vine destructively harvested before separation into various plant organs, as identified.

Matthews, NC) and was analyzed using ICP (1100 ICP; Thermo Jarrell Ash, Franklin, MA).

Before root sampling, surface and subsurface soil samples were collected using a $2.5-\mathrm{cm}$ i.d. soil probe. A composite of 10 cores was taken at two sampling depths (0-30 and 30-75 $\mathrm{cm})$ at each whole plant sampling point. The samples were sent to a soil test laboratory and were extracted for $\mathrm{P}, \mathrm{K}, \mathrm{Ca}$, and $\mathrm{Mg}$ using a Mehlich III extraction (Mehlich, 1984) and ICP analysis. Soil $\mathrm{N}$ was determined as $\mathrm{NH}_{4}-\mathrm{N}$ and $\mathrm{NO}_{3}-\mathrm{N}$ using a $1 \mathrm{~N} \mathrm{KCl}$ extraction and colorimetric analysis using $\mathrm{Cd}$ reduction (Dahnke, 1990). The results did not indicate a lack of any nutrients (data not given).

An initial data analysis was conducted using Proc GLM of SAS (version 9.2 for Windows; SAS Institute, Cary, NC) to evaluate the influence of the main and interactive effects on tissue nutrient concentration and content (Table 2). Additionally, nutrient content was analyzed relative to nutrient concentration, plant dry weight, and the interaction between concentration and dry weight. All were highly significantly correlated for $\mathrm{C}, \mathrm{N}, \mathrm{P}, \mathrm{K}, \mathrm{Ca}$, and $\mathrm{Mg}(P<0.01)$, indicating a combination of plant mass and nutrient concentration both contributing to plant nutrient content. Data were subsequently analyzed using analysis of variance with SPSS (version 15.0; SPSS, Chicago) to examine changes in dry weight and nutrient concentrations of each macronutrient in all plant parts over time. Because dry weight was highly significantly different by year, data were analyzed separately for each year. Mean separation used least significant difference at $P<0.05$. Modeling whole plant nutrient uptake and net nutrient movement between various plant parts was accomplished by calculating the content of each macronutrient within each plant part (dry weight $x$ concentration) divided by the number of days between sampling dates. 
Table 2. Significance [probability and least squares difference (LSD) values] of dry weight, nutrient content, and nutrient concentration among different growth stages, organs, as well as the interactions between growth stage and organ of 'Concord' grape destructively harvested in 2006 and 2007.

\begin{tabular}{|c|c|c|c|c|c|c|c|c|c|c|c|c|c|}
\hline \multirow[b]{3}{*}{ Parameter } & \multicolumn{5}{|c|}{2006} & \multicolumn{5}{|c|}{2007} & \multicolumn{3}{|c|}{ Years combined } \\
\hline & \multicolumn{2}{|c|}{ Growth stage (GS) } & \multicolumn{2}{|c|}{ Organ $(\mathrm{O})$} & \multirow{2}{*}{$\begin{array}{c}\mathrm{GS} \times \mathrm{O} \\
P\end{array}$} & \multicolumn{2}{|c|}{ Growth stage (GS) } & \multicolumn{2}{|c|}{ Organ $(\mathrm{O})$} & \multirow{2}{*}{$\begin{array}{c}\mathrm{GS} \times \mathrm{O} \\
P\end{array}$} & \multirow{2}{*}{$\begin{array}{c}\text { GS } \\
P\end{array}$} & \multirow{2}{*}{$\begin{array}{l}\text { Organ } \\
P\end{array}$} & \multirow{2}{*}{$\begin{array}{c}\mathrm{GS} \times \mathrm{C} \\
P\end{array}$} \\
\hline & $P$ & LSD & $P$ & LSD & & $P$ & LSD & $P$ & LSD & & & & \\
\hline Dry wt & $<0.001$ & 102.73 & $<0.001$ & 111.14 & $<0.001$ & $<0.001$ & 100.57 & $<0.001$ & 110.56 & $<0.001$ & $<0.001$ & $<0.001$ & $<0.001$ \\
\hline $\mathrm{N}$ content & $<0.001$ & 0.98 & $<0.001$ & 1.06 & $<0.001$ & $<0.001$ & 0.77 & $<0.001$ & 0.84 & $<0.001$ & $<0.001$ & $<0.001$ & $<0.001$ \\
\hline content & $<0.001$ & 0.16 & $<0.001$ & 0.17 & $<0.001$ & $<0.001$ & 0.14 & $<0.001$ & 0.15 & $<0.001$ & $<0.001$ & $<0.001$ & $<0.001$ \\
\hline K content & $<0.001$ & 1.10 & $<0.001$ & 1.19 & $<0.001$ & $<0.001$ & 1.15 & $<0.001$ & 1.25 & $<0.001$ & $<0.001$ & $<0.001$ & $<0.001$ \\
\hline Mg content & $<0.001$ & 0.14 & $<0.001$ & 0.16 & $<0.001$ & $<0.001$ & 0.14 & $<0.001$ & 0.15 & $<0.001$ & $<0.001$ & $<0.001$ & $<0.001$ \\
\hline concn & $<0.001$ & 0.27 & $<0.001$ & 0.30 & $<0.001$ & $<0.001$ & 0.18 & $<0.001$ & 0.19 & $<0.001$ & $<0.001$ & $<0.001$ & $<0.001$ \\
\hline $\mathrm{N}$ concn & $<0.001$ & 0.06 & $<0.001$ & 0.07 & $<0.001$ & $<0.001$ & 0.12 & $<0.001$ & 0.13 & $<0.001$ & $<0.001$ & $<0.001$ & $<0.001$ \\
\hline P concn & $<0.001$ & 0.03 & $<0.001$ & 0.03 & $<0.001$ & $<0.001$ & 0.02 & $<0.001$ & 0.02 & $<0.001$ & $<0.001$ & $<0.001$ & $<0.001$ \\
\hline $\mathrm{K}$ concn & $<0.001$ & 0.05 & $<0.001$ & 0.06 & $<0.001$ & $<0.001$ & 0.04 & $<0.001$ & 0.05 & $<0.001$ & $<0.001$ & $<0.001$ & $<0.001$ \\
\hline $\mathrm{Ca}$ concn & $<0.001$ & 0.05 & $<0.001$ & 0.05 & $<0.001$ & $<0.001$ & 0.06 & $<0.001$ & 0.07 & $<0.001$ & $<0.001$ & $<0.001$ & $<0.001$ \\
\hline
\end{tabular}

\section{Results and Discussion}

Dry matTer and Carbon. The highest vine biomass occurred at harvest, which was about double of that in winter, budbreak, three- to four-leaf stage, and bloom (Fig. 2). The annual growth from shoots, shoot tips, leaf blades, petioles, and clusters showed significant changes over time. The dry weight of coarse and fine roots did not change significantly over the growing season, whereas the trunk and cordon woody tissue mass decreased from $\approx 44 \%$ of the whole vine after dormancy/budbreak to a low of about $35 \%$ during the active growing season, and did not increase again until after fruit harvest (Fig. 2).

Changes in $\mathrm{C}$ concentrations of various vine parts were consistent between years. Carbon concentration was significantly lowest in the petioles $(41 \%-42 \%)$, and lower in the clusters at harvest (about $45 \%$ ) than the other plant organs $[46 \%-48 \%$ (Fig. 3A)]. This reflects the fact that the bulk of dry weight is the cell wall, which consists mainly of cellulose, a carbohydrate polymer. Due to a small variation of carbon concentrations in plant organs compared with other nutrients, the seasonal pattern of carbon content was nearly analogous to the seasonal pattern of plant dry weight.

In both years, there was a significant decrease in trunk and cordon (woody tissue) dry weight between budbreak and the three- to four-leaf stage in both years (Fig. 2). Additionally, there was a significant increase in woody tissue dry weight from

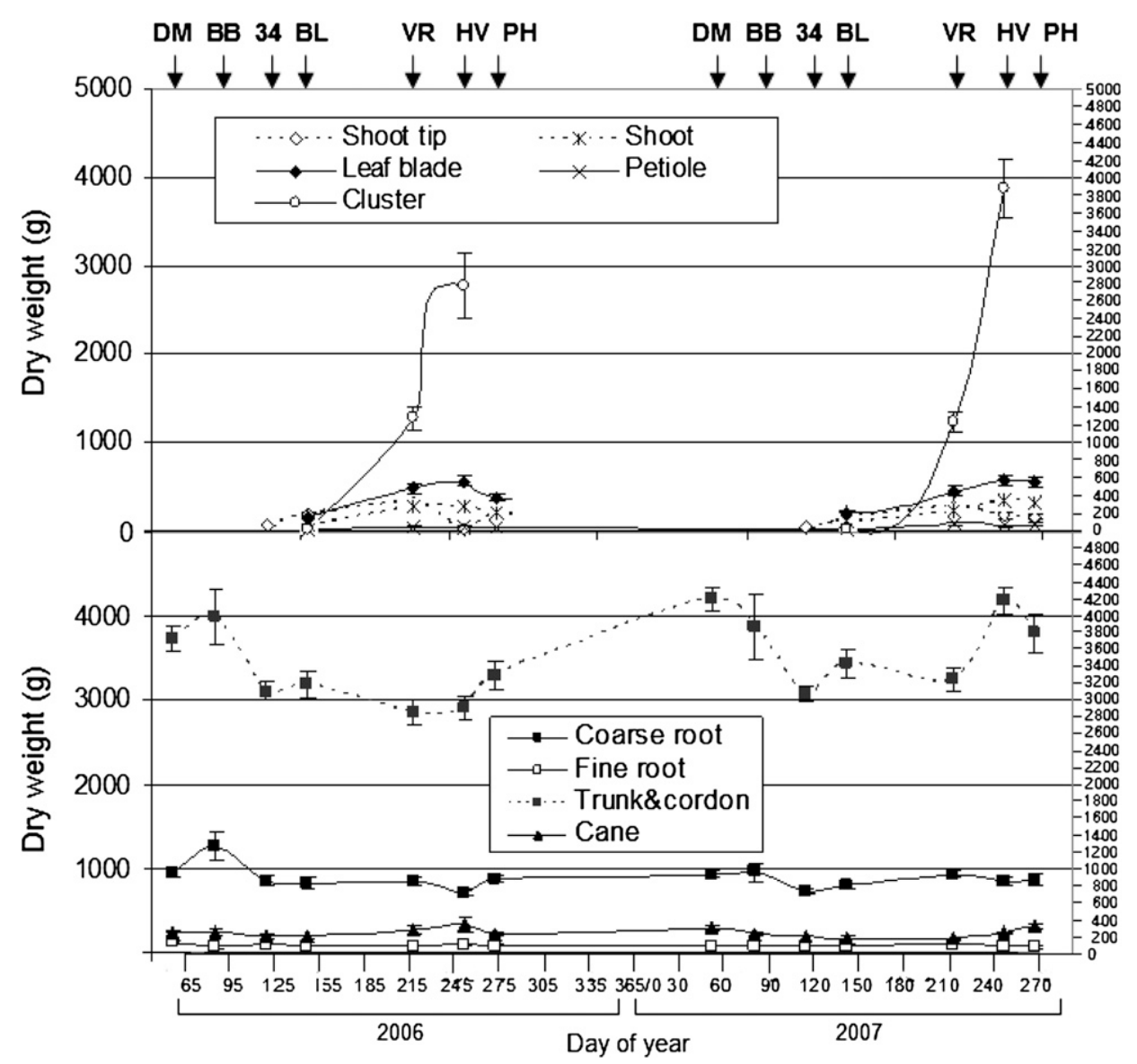

Fig. 2. Seasonal changes in dry weight of 'Concord' grape plant parts destructively harvested in 2006 and 2007 from a vineyard in Prosser, WA. Arrows at the top of graph indicate the time of dormant (DM), budbreak (BB), three- to four-leaf stage (34), bloom (BL), veraison (VR), harvest (HV), and postharvest (PH). SE are represented as bars above and below the mean. veraison to postharvest and through to dormancy from 2006 to 2007 and from veraison to harvest in 2007. This was consistent with losses and gains in $\mathrm{C}$ content in the woody tissues at the same time. Although it is expected that there would be 


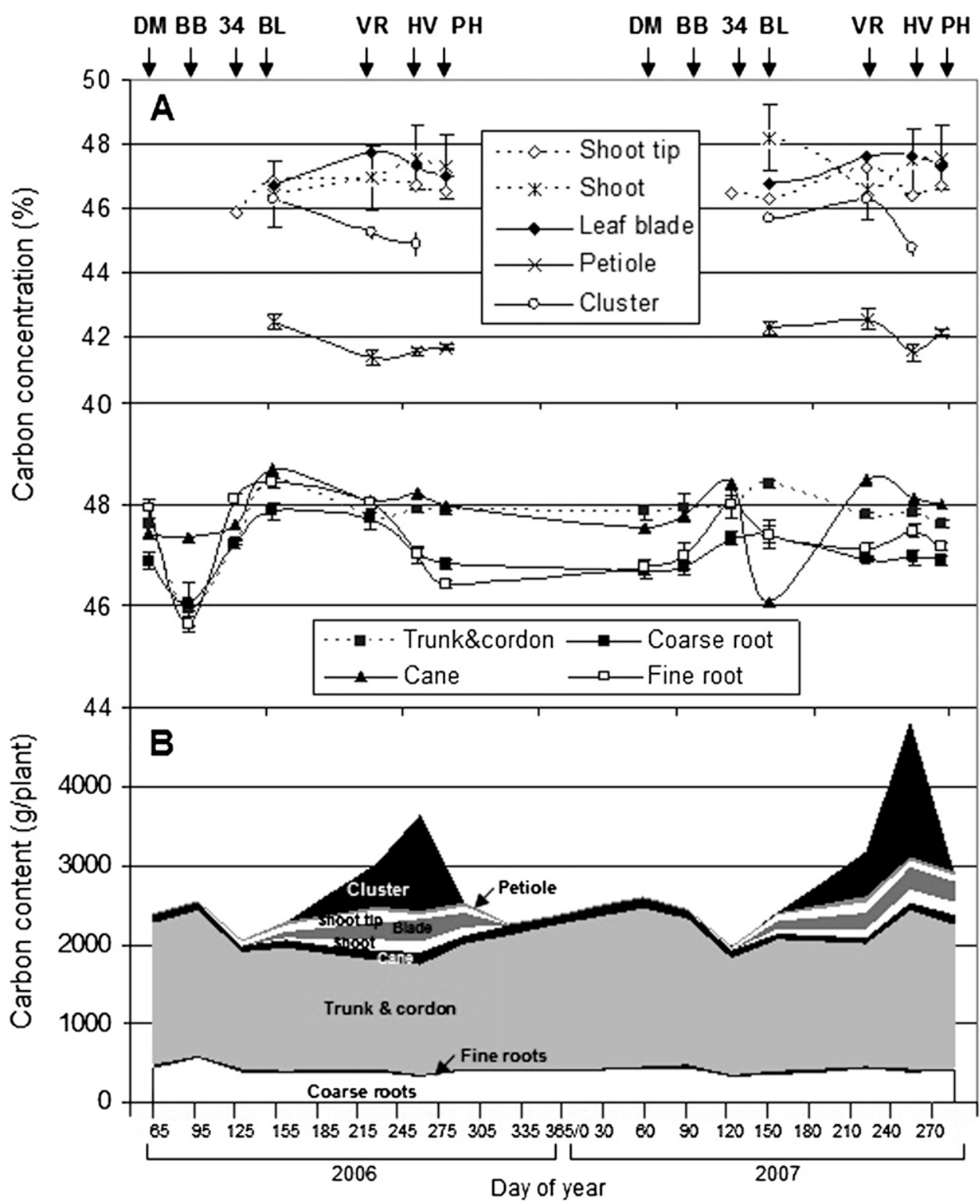

Fig. 3. Seasonal change in concentrations $(\mathbf{A})$ and contents $(\mathbf{B})$ of carbon in various organs of 'Concord' grape destructively harvested in 2006 and 2007. Arrows at the top of graph indicate the time of dormant (DM), budbreak (BB), three- to four-leaf stage (34), bloom (BL), veraison (VR), harvest (HV), and postharvest (PH). SE are represented as bars above and below the mean.

movement of $\mathrm{C}$ to develop new growth in the vine, the reserve $\mathrm{C}$ lost from the trunk and cordon between bud burst and the threeto four-leaf stage was at least 100 times higher than the amount of $\mathrm{C}$ gained in the annual tissues during that same interval. It is possible that some was lost to respiration and some to sap loss from bleeding canes, but it is also possible that the differences were due to vine size of randomly chosen vines despite efforts to decrease this variability by working within a narrow range of vine sizes.

Vine MACRONUTRIENT CONCENTRATION. While the changes in $\mathrm{N}$ concentrations of different vine organs were similar between years, higher $\mathrm{N}$ concentrations were found in shoot tips and leaf blades at the three- to four-leaf stage, and lower $\mathrm{N}$ concentration was found in clusters at bloom in 2007 when compared with 2006 (Fig. 4A). Shoot tip and leaf blade N concentrations decreased significantly between veraison and postharvest in 2006, but in
2007, the decrease occurred after harvest. In both years, trunk, cordon, and coarse root $\mathrm{N}$ concentrations remained constant in the early season, significantly decreased from bloom to veraison, and significantly increased from veraison to harvest.

Changes in $\mathrm{P}$ concentrations of various vine organs were similar in both years, except shoot tips that showed greater decrease and cane that showed greater increase from the three- to four-leaf stage to bloom stage in 2007 versus 2006 (Fig. 5A). Phosphorus concentrations were highest and most dynamic in shoot tips, petioles, clusters, and leaf blades, whereas $\mathrm{P}$ concentrations in permanent structures (trunk, cordons, and coarse roots) showed little change throughout the two growing seasons. P concentrations were highest at the three- to four-leaf stage or at bloom stages and declined throughout the growing season, reaching the lowest values at harvest or at postharvest.

The $\mathrm{K}$ concentration patterns of various vine components were consistent between years. At bloom, higher $\mathrm{K}$ concentrations were found in petioles and leaf blades, and lower $\mathrm{K}$ concentration was found in shoots at bloom in 2007 compared with 2006 (Fig. 6A). Early season K concentrations were highest in petioles, clusters, shoot tips, and leaf blades and then declined throughout the season, reaching the lowest values at harvest or at postharvest, although cluster and petiole $\mathrm{K}$ remained significantly higher than the other tissues in both years. There was no measurable change in woody tissue $\mathrm{K}$ concentration (trunk, cordon, and roots) with time of season.

While concentrations of $\mathrm{Ca}$ in shoot tips, leaf blades, and petioles significantly increased from bloom to harvest, cluster $\mathrm{Ca}$ concentration decreased until the end of the season in both years (Fig. 7A). After harvest, however, Ca concentrations in leaf blades and petioles slightly decreased in 2006 but seemed to increase in 2007. Ca concentrations in fine roots (both years) fluctuated throughout the growing season, whereas a large drop of $\mathrm{Ca}$ concentration in coarse roots at veraison occurred in 2006, but not in 2007 .

Magnesium concentrations were higher and most dynamic in petioles, shoot tips, and clusters, whereas $\mathrm{Mg}$ concentration in other vine parts were much lower and showed little change throughout the two growing seasons (Fig. 8A). Over time, in both years, $\mathrm{Mg}$ concentrations increased in petioles but decreased in clusters, especially from bloom to veraison. $\mathrm{Mg}$ concentration in shoot tips dropped from the three- to four-leaf stage to bloom 


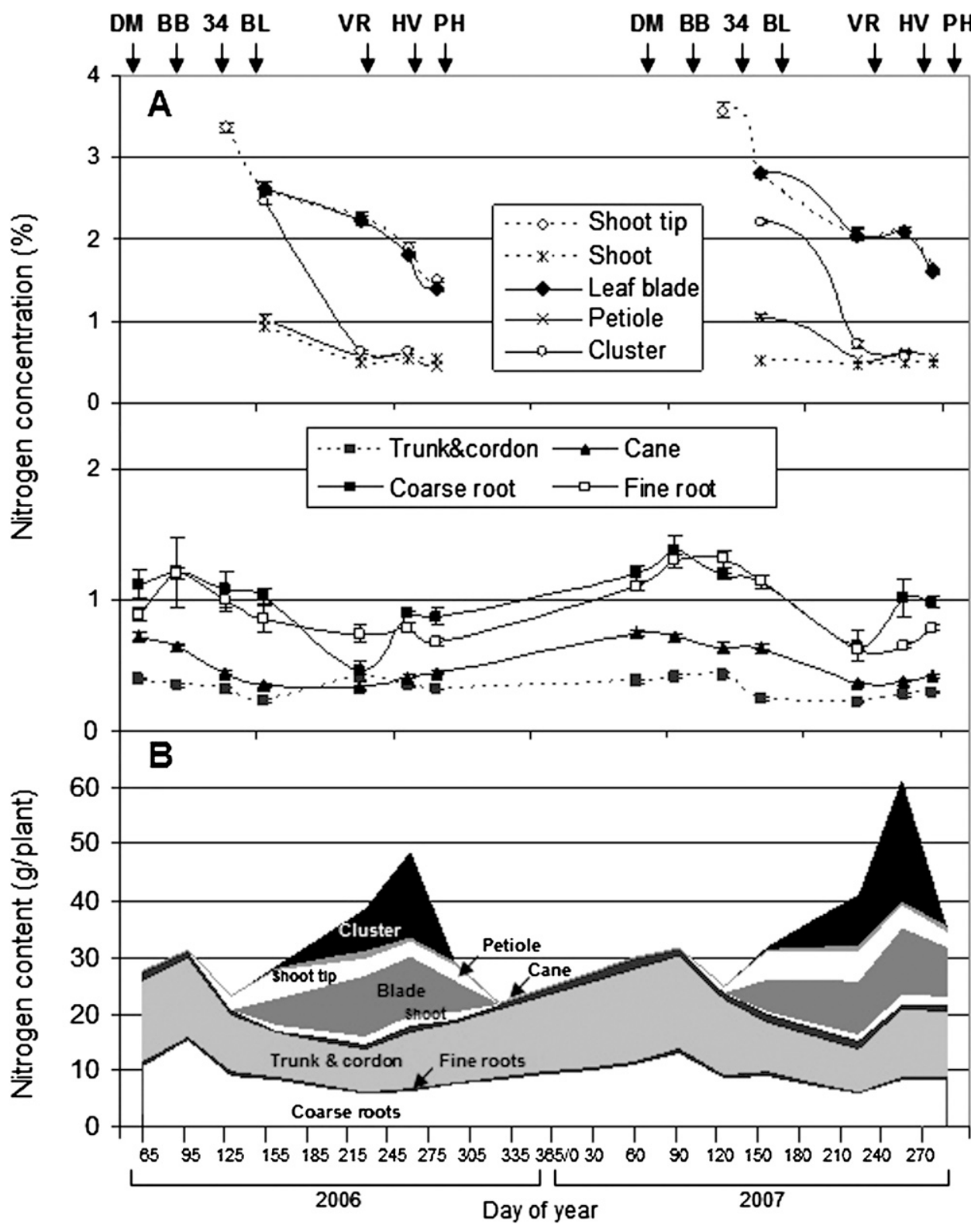

Fig. 4. Seasonal change in concentrations (A) and contents $(\mathbf{B})$ of nitrogen in various organs of 'Concord' grape destructively harvested in 2006 and 2007. Arrows at the top of graph indicate the time of dormant (DM), budbreak (BB), three- to four-leaf stage (34), bloom (BL), veraison (VR), harvest (HV), and postharvest (PH). SE are represented as bars above and below the mean.

stage before significantly increasing until the end of the season. From bloom to veraison, leaf blade $\mathrm{Mg}$ concentrations slightly increased in 2006 and slightly decreased in 2007 . The changes were small when compared with other macronutrients.

MaCronUtrient UPTAKe and PARTITIONING. As shown in Figs. 4B through 6B, respectively, vine $\mathrm{N}, \mathrm{P}$, and $\mathrm{K}$ contents in woody tissue changed little between dormancy and budbreak with the exception of a slight increase in the coarse root fraction. However, there was a large drop in nutrient content of the woody tissues by the three- to four-leaf stage, likely related to the significant decrease of trunk and cordon biomass from budbreak to the three- to four-leaf stage in both years (Fig. 2). The gradual decrease of these nutrient concentrations also suggested that the new growth of grapevines depends on the nutrients stored in permanent structures. Shoot-tip N, P, and K content increased from the three- to four-leaf stage through bloom but then began to decrease for the remainder of the season. Previous studies have reported $\mathrm{N}$ concentration decreases during the growing season (Löhnertz, 1991; Wermelinger, 1991; Williams and Biscay, 1991). Our results are consistent with previous findings of a dilution effect of not only $\mathrm{N}$, but also $\mathrm{P}$ and $\mathrm{K}$, concentration throughout the season in response to rapid leaf expansion and nutrient translocation from shoot tips to leaf blades and clusters.

In both years, the whole vine $\mathrm{N}$ content gradually increased from the three- to four-leaf stage to veraison before rapidly increasing from veraison to harvest, while $\mathrm{P}$ and $\mathrm{K}$ contents showed a rapid increase from the three- to four-leaf stage to harvest. Nitrogen concentration in clusters rapidly decreased after bloom, while $\mathrm{P}$ concentration slightly decreased and $\mathrm{K}$ concentration remained stable until the end of the season. After reaching the maximum in leaf blades at bloom, $\mathrm{N}$ concentration declined more slowly than $\mathrm{P}$ and $\mathrm{K}$. There was a slow decrease in $\mathrm{N}$ concentration in shoot tips and leaf blades compared with $\mathrm{P}$ and $\mathrm{K}$ concentration. While $\mathrm{P}$ and $\mathrm{K}$ rapidly accumulated in the clusters after veraison, there was lower $\mathrm{N}$ accumulation in the clusters after veraison. By harvest, the bulk $(40 \%-60 \%)$ of $\mathrm{P}$ and $\mathrm{K}$ were accumulated in the clusters, whereas about $30 \%$ of the $\mathrm{N}$ was allocated to the clusters by bloom period and another $30 \%$ was allocated to other aboveground annual tissues (shoots, shoot tips, leaf blades, and petioles) during grape maturation. Thus, the nitrogen pathway during the fruit development differs significantly from that for $\mathrm{P}$ and $\mathrm{K}$ in these organs. Clusters were a stronger sink for $\mathrm{P}$ and $\mathrm{K}$, whereas leaves and clusters were important $\mathrm{N}$ sinks.

While $\mathrm{K}$ content was most closely related to fruit development and production, $\mathrm{N}$ supply was most closely related to leaf development. Total $\mathrm{N}$ content per vine was significantly higher than $\mathrm{K}$ during the early growth stages (from dormant to bloom), whereas from veraison and harvest, total $\mathrm{N}$ content was slightly lower than $\mathrm{K}$ in 2006 and nearly equal in 2007, which was probably due to relatively higher crop load in 2007. Potassium was the most evident element in the developing clusters and its movement to the fruits appears to nearly linear increase from to bloom to harvest in both years, suggesting the highest accumulation rate in clusters after veraison compared with the other elements. Similar trends of K accumulation were reported in 


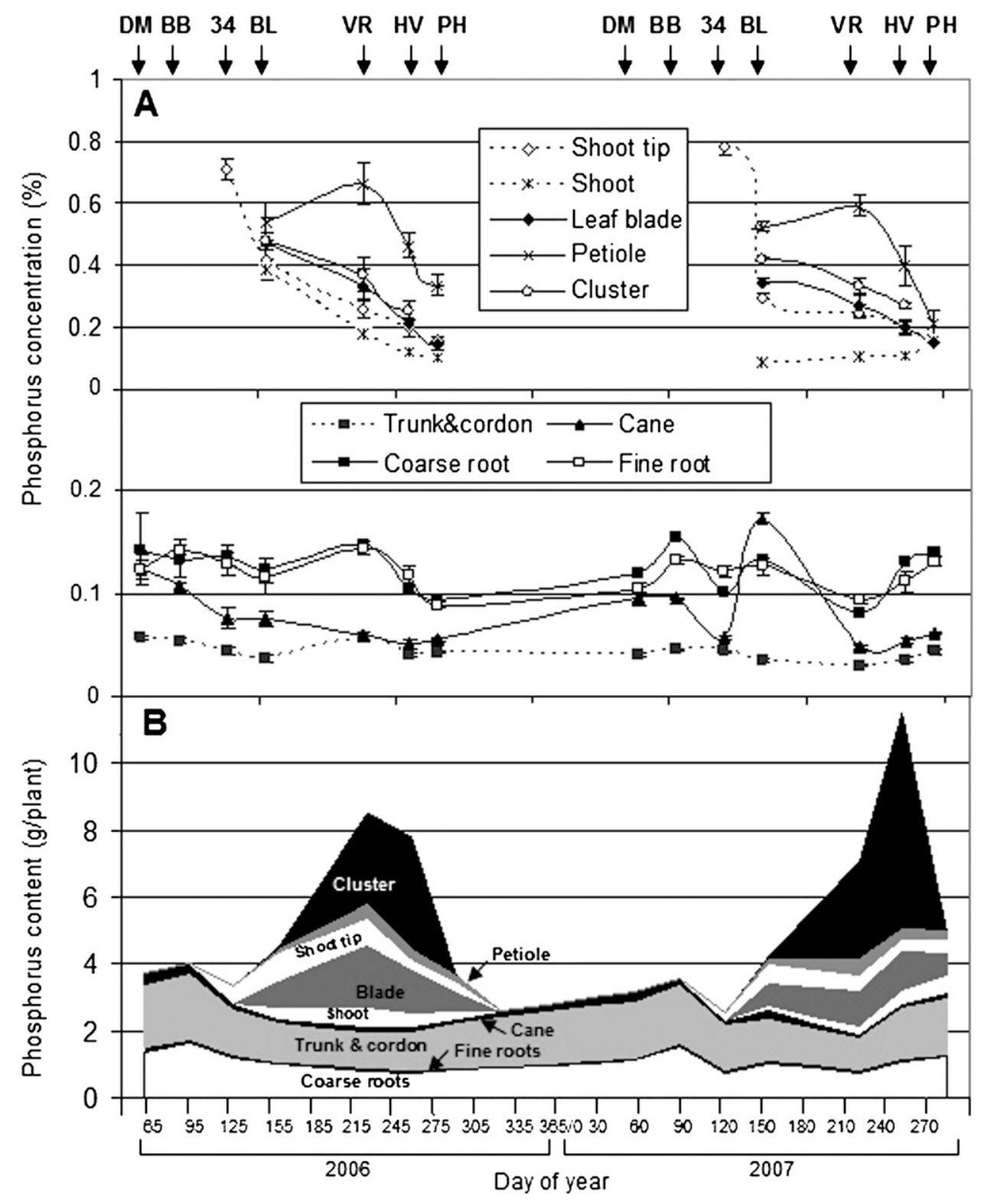

Fig. 5. Seasonal change in concentrations $(\mathbf{A})$ and contents $(\mathbf{B})$ of phosphorus in various organs of 'Concord' grape destructively harvested in 2006 and 2007. Arrows at the top of graph indicate the time of dormant (DM), budbreak (BB), three- to four-leaf stage (34), bloom (BL), veraison (VR), harvest (HV), and postharvest (PH). SE are represented as bars above and below the mean.

Conradie (1981), Mullins et al. (1992), Schaller et al. (1992), Rogiers et al. (2006), Schreiner et al. (2006), and Williams and Biscay (1991). Furthermore, the prevailing accumulation of $\mathrm{K}$ in berry pulp and skin tissue supported a relative role of $\mathrm{K}$ in cell expansion (Rogiers et al., 2006).

In both years, N, P, and $\mathrm{K}$ were remobilized back to the woody tissues after veraison. After reaching the lowest content in the trunk, cordon, and coarse roots at veraison, woody tissue $\mathrm{N}, \mathrm{P}$, and $\mathrm{K}$ content increased again until the end of season. This is supported by the large drop in $\mathrm{N}, \mathrm{P}$, and $\mathrm{K}$ concentrations in leaf blades and petioles postharvest. N, P, and K content in trunk, cordons, and coarse roots postharvest were lower than at the beginning of season. This suggests that movement of nutrient from annual tissues back to woody tissues continued after the postharvest sample collection until the grapevines entered dormancy. The finding is consistent with Löhnertz (1991), who found that accumulation of $\mathrm{N}$ in permanent structures occurred from veraison to harvest, Alexander (1958), who found translocation of $\mathrm{N}$ back from leaves to woody tissues, and Schreiner et al. (2006), who found $\mathrm{N}$ losses between harvest and leaf fall. However, the result is in contrast with results reported by Conradie (1980, 1981, 1986), who showed substantial uptake of N, P, and $\mathrm{K}$ at postharvest. Tagliavini et al. (2000) have reported similar findings in deciduous fruit trees. It is possible that the differences between these findings and ours and others could be related to plant age or climatic conditions.

Throughout the growing season, average total uptake per plant of $\mathrm{N}, \mathrm{P}$, and $\mathrm{K}$ was 21.2 , 4.9, and $41.8 \mathrm{~g}$, respectively, in 2006; and 32.6, 8.9, and $65.5 \mathrm{~g}$, respectively, in 2007 (Table 3). There was greater uptake of N, $\mathrm{P}$, and $\mathrm{K}$ in 2007 compared with 2006, which corresponds to a higher cluster biomass in the 2007 (Fig. 2). The amount of $\mathrm{N}$ uptake per plant for these established vines was about two times more ( 21 vs. $13 \mathrm{~g} / \mathrm{vine}$ ) than Bates et al. (2002) found in 3-yearold 'Concord' grapes. The mature 'Concord' grapevines appeared to have considerably higher N, P, and $\mathrm{K}$ uptake when compared with $8 \mathrm{~g} \mathrm{~N}$, $1.5 \mathrm{~g} \mathrm{P}$, and $19 \mathrm{~g} \mathrm{~K}$ uptake from budbreak through leaf fall in established, own-rooted 'Pinot Noir' vines (Schreiner et al., 2006) and $18 \mathrm{~g} \mathrm{~N}$ and $25 \mathrm{~g} \mathrm{~K}$ uptake established 'Cabernet Sauvignon' vines grafted on $5 \mathrm{C}$ rootstocks (Williams and Biscay, 1991). Hence, the differences in vine age, size, rootstock, and species (Vitis vinifera vs. labruscana) seem to have major impacts on nutrient uptake because the 'Concord' grapevines in this study were about three times larger than the juvenile 'Concords' reported by Bates et al. (2002) and at least two times larger in vine size and three times larger in crop level compared with the mature 'Cabernet Sauvignon' (Williams and Biscay, 1991).

The timing of nutrient uptake differed in this study when compared with others. In both years $\approx 90 \%$ to $95 \%$ of the $\mathrm{N}$ uptake 'Concord' grape occurred between bloom and harvest (Table 3), which differs from the other reported findings. Estimating the values from original figures (rounding to the nearest integer), the results in the reported literature are as follows. Conradie (2005) found that remarkably consistent $\mathrm{N}$ uptake $(10 \%-35 \%)$ by 2 -year-old 'Chenin Blanc' occurred in each growth stage throughout the growing season. Schreiner et al. (2006) found that $87 \% \mathrm{~N}$ uptake by mature 'Pinot Noir' occurred between budbreak to veraison, Williams and Biscay 


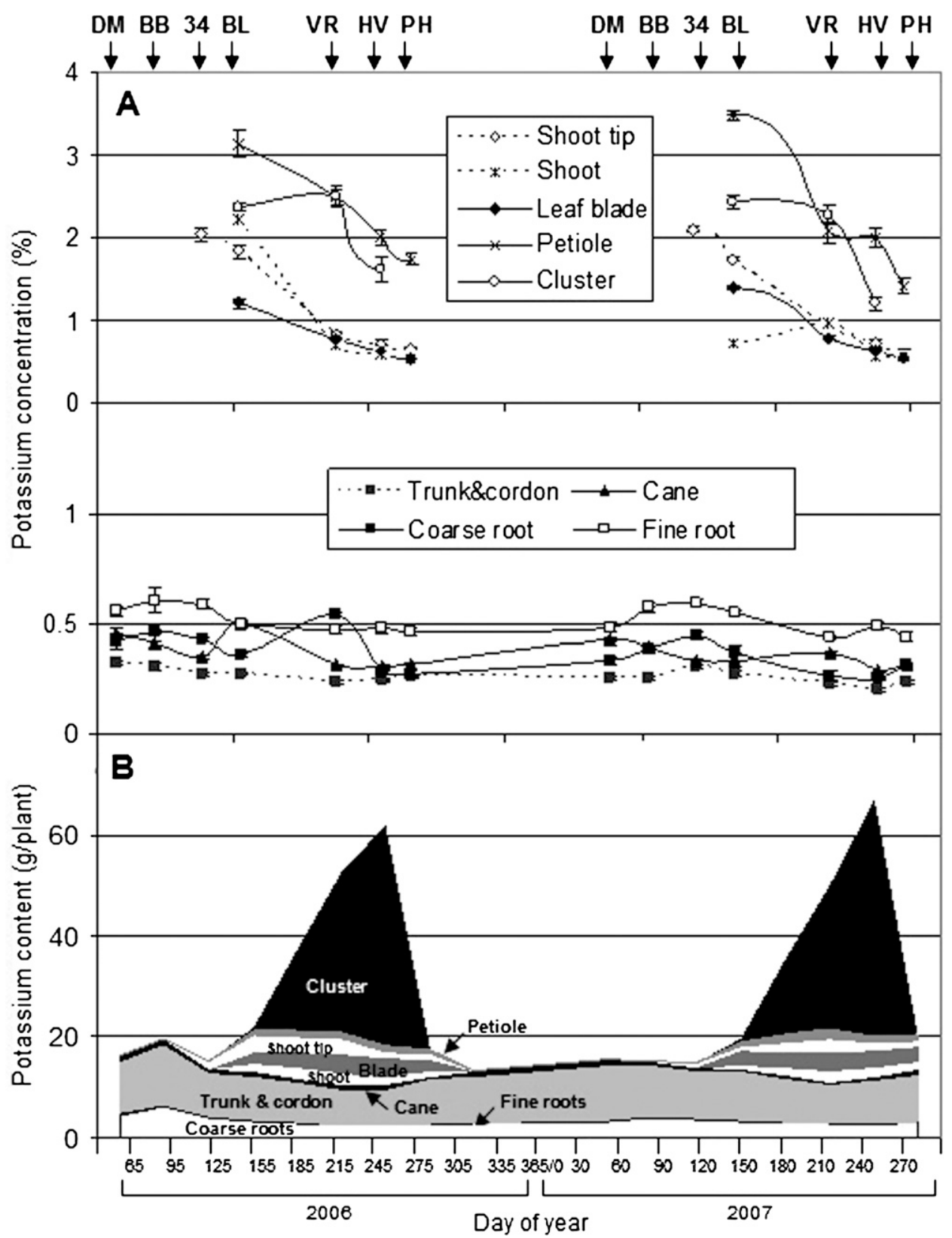

Fig. 6. Seasonal change in concentrations (A) and contents $(\mathbf{B})$ of potassium in various organs of 'Concord' grape destructively harvested in 2006 and 2007. Arrows at the top of graph indicate the time of dormant (DM), budbreak (BB), three- to four-leaf stage (34), bloom (BL), veraison (VR), harvest (HV), and postharvest (PH). SE are represented as bars above and below the mean.

(1991) found that $86 \% \mathrm{~N}$ uptake by mature 'Cabernet Sauvignon' occurred between bloom and veraison, and Hanson and Howell (1995) found that $60 \% \mathrm{~N}$ uptake by established 'Concord' grapevines occurred between bloom and veraison. Conversely, we found that the highest uptake of $\mathrm{P}$ and $\mathrm{K}$ occurred between bloom and veraison, which is consistent with previous studies regardless of cultivar or vine age (Conradie, 1981; Schreiner et al., 2006; Williams and Biscay, 1991).

Others have found that peak $\mathrm{N}$ uptake occurred before veraison, but our results showed that there was significant $\mathrm{N}$ uptake before and after veraison. One factor that likely contributes to the difference in uptake timing in this study when compared with previous work is that there was a larger proportion of vine mass in woody tissues due to vine age, enabling the mature vines to use nutrients reserves during early growth stages. Additionally, in comparison with wine grapes, juice grapes typically have a larger canopy and higher crop, which could trigger the plant to have prolonged $\mathrm{N}$ uptake period to fulfill the fruit demand. The intensity of vine $\mathrm{N}$ uptake between veraison and harvest suggests that the newly assimilated $\mathrm{N}$ was not only partitioned into leaves and clusters, but was also restored to woody tissues. To this end, $\mathrm{N}$ appeared to be mainly partitioned among woody tissues $(32 \%-33 \%)$, leaves and shoot tips $(25 \%-27 \%)$, and clusters (32\%-34\%) at harvest (Fig. 4).

Based on nutrient uptake and redistribution patterns of $\mathrm{N}, \mathrm{P}$, and $\mathrm{K}$, it is implicit that if fertilizer supplements are need, they should be applied before bloom, but not before budbreak because the grapevine has no need at this stage and excessive rainfall or irrigation may cause unwanted leaching of soluble nutrients. Split-application of fertilizers could enhance the efficiency of nutrient use in growth and production. In addition, fertilization is not required at postharvest for this crop in cool climate regions, as uptake does not occur after harvest.

The average total uptake per vine throughout the growing season was $18.2 \mathrm{~g}$ of $\mathrm{Ca}$ and $3.3 \mathrm{~g}$ of $\mathrm{Mg}$ in 2006 , and $44.2 \mathrm{~g}$ of $\mathrm{Ca}$ and $7.9 \mathrm{~g}$ of $\mathrm{Mg}$ in 2007 (Table 3). Although $\mathrm{Mg}$ is classified as a phloem-mobile nutrient, in 'Concord' grape, the accumulation pattern of $\mathrm{Mg}$ almost paralleled Ca. In 2006, it appeared that after highest uptake occurred from bloom to veraison, the whole vine $\mathrm{Ca}$ and $\mathrm{Mg}$ content continued to progressively increase until reaching the highest content at harvest. In 2007 , $\mathrm{Ca}$ and $\mathrm{Mg}$ uptake was consistent, and high, from bloom to harvest (Figs. 7B and 8B). In both years, $\mathrm{Ca}$ and $\mathrm{Mg}$ concentrations in the cluster decreased after bloom, while $\mathrm{Ca}$ concentration in leaf blades, petioles, and shoot tips increased from bloom to postharvest. Magnesium increased only in the petiole and remained constant in leaf blades and shoot tips. Calcium and $\mathrm{Mg}$ concentrations in leaf blades, shoot tips, and petioles did not decline after harvest as occurred with N, P, and K. This suggests that neither $\mathrm{Mg}$ nor $\mathrm{Ca}$ migrated back from leaves into woody tissues.

Although the trends of nutrient uptake and accumulation were similar, $\mathrm{Ca}$ or $\mathrm{Mg}$ was partitioned to different vine organs. While the trunk and cordon woody tissue had a higher $\mathrm{Ca}$ and $\mathrm{Mg}$ content than any other organs, there was a very high 


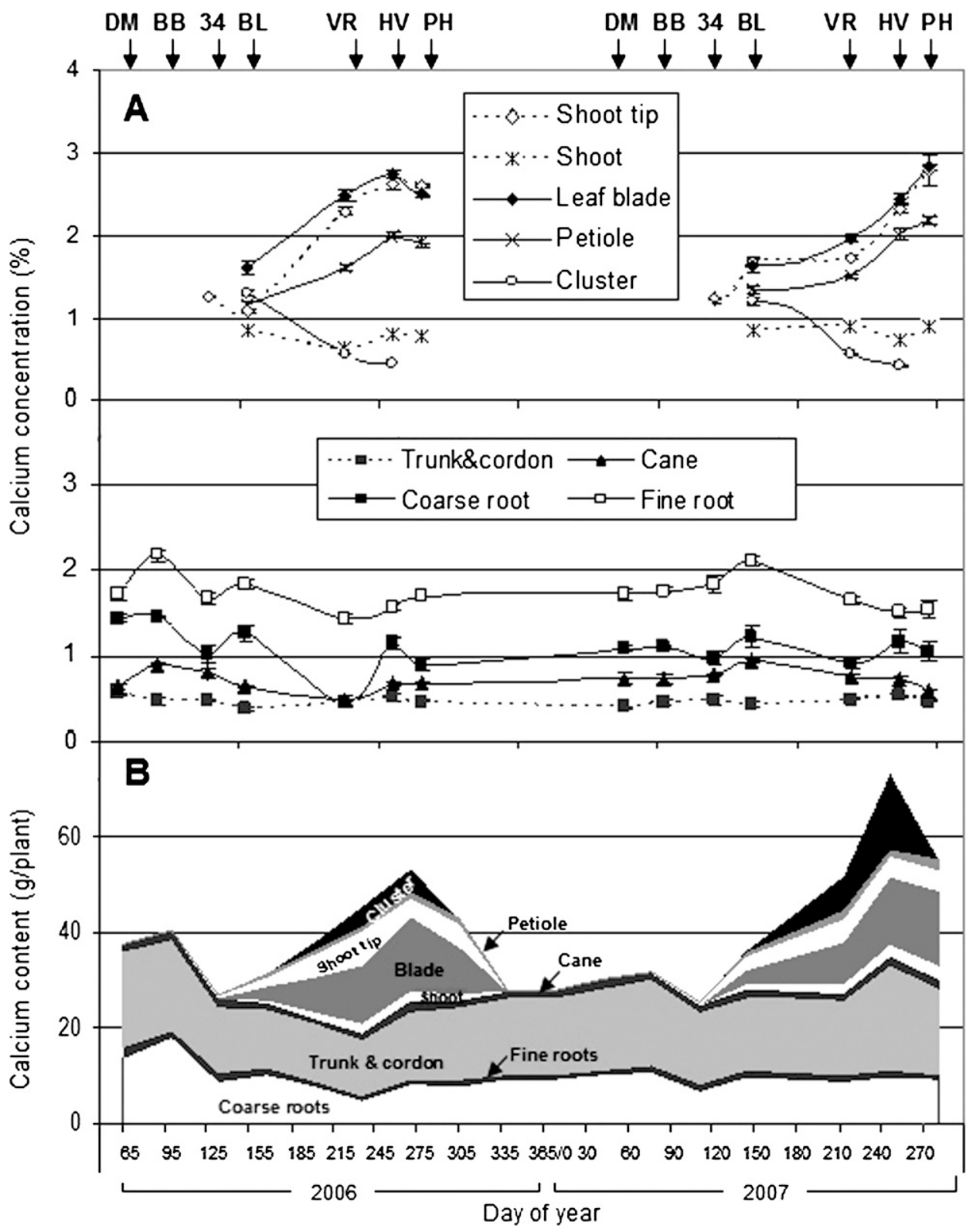

Fig. 7. Seasonal change in concentrations (A) and contents (B) of calcium in various organs of 'Concord' grape destructively harvested in 2006 and 2007. Arrows at the top of graph indicate the time of dormant (DM), budbreak (BB), three- to four-leaf stage (34), bloom (BL), veraison (VR), harvest (HV), and postharvest (PH). SE are represented as bars above and below the mean.

proportion of the plant $\mathrm{Ca}$ in the coarse root fraction, while $\mathrm{Mg}$ was distributed between leaves and clusters. The higher content of $\mathrm{Mg}$ in the actively growing tissues than $\mathrm{Ca}$ is consistent with its known higher mobility in the plant phloem (Epstein and Bloom, 2005) as well as the plant xylem from root uptake by mass flow and interception (Barber, 1984), probably serving as the major supply mechanism that keeps pace with $\mathrm{Mg}$ demand and transfers from roots and shoots.

These mature 'Concord' vines had a similar Mg uptake but three times higher Ca uptake than what Schreiner et al. (2006) found in mature 'Pinot Noir' vines $(\approx 10 \mathrm{~g}$ of Ca and $4.5 \mathrm{~g}$ of $\mathrm{Mg}$ uptake per vine during the growing season). The higher uptake of $\mathrm{Ca}$ could be driven by differences in canopy and yield goals of the two different Vitis species, however, a more likely explanation is a difference in Ca supply in the soils in the two different growing regions. The 'Concord' vineyard was in a fine sandy loam, $\mathrm{pH} 7.8$ to 8.4 , with an average $15,450 \mathrm{mmol} \cdot \mathrm{kg}^{-1} \mathrm{Ca}$, whereas the 'Pinot Noir' was in a silty clay loam, $\mathrm{pH} 5.3$ to 5.6 , with an average 1410 $\mathrm{mmol} \cdot \mathrm{kg}^{-1} \mathrm{Ca}$. This is further supported by the literature on plant response to $\mathrm{Ca}$ availability. It has been reported that plants regulate $\mathrm{Ca}$ accumulation over time relative to the natural abundance of $\mathrm{Ca}$ and the very low $\mathrm{Ca}$ requirement by controlling the distribution of $\mathrm{Ca}$ within the cell (Marschner, 2002). Calcium oxalate crystal deposition can occur within the vacuoles of cells (Kinzel, 1989) or associated with the cell wall (Demarty et al., 1984), which is the main component of plant dry weight. In other words, the annual increase in permanent tissue biomass resulted in increased vine $\mathrm{Ca}$ content.

Although most studies have found $\mathrm{N}$ to be the most abundant mineral element in grapevines (Bates et al., 2002; Conradie, 2005; Schreiner et al., 2006; Williams and Biscay, 1991), the 'Concord' vines in this study had a higher total Ca content than $\mathrm{N}$ content throughout growing season. Woody tissues such as trunk, cordons, and coarse roots had higher content of $\mathrm{Ca}$ than $\mathrm{N}$ at every growth stage, whereas annual tissues such as shoot tips, leaf blades, and clusters showed higher content of $\mathrm{N}$ than $\mathrm{Ca}$ at bloom. The average $\mathrm{N}$ and $\mathrm{Ca}$ content in woody tissues (7-8 $\mathrm{g}$ of $\mathrm{N}$ and $12-15 \mathrm{~g}$ of $\mathrm{Ca}$ ) and leaf blade (9-11 $\mathrm{g}$ of $\mathrm{N}$ and 9$12 \mathrm{~g}$ of $\mathrm{Ca}$ ) at veraison in this study (Figs. 4B and 7B) were consistent with those of Schreiner et al. (2006), who reported $\approx 14 \mathrm{~g}$ of $\mathrm{N}$ and $19 \mathrm{~g}$ of $\mathrm{Ca}$ in woody tissues and $\approx 10 \mathrm{~g}$ of $\mathrm{N}$ and $8 \mathrm{~g}$ of $\mathrm{NCa}$ in leaf blades of 'Pinot Noir' vines at veraison.

The DIFFERENCE BETWEen CANOPY AND ROOT DEVELOPMENT. Apart from a very small amount of young white fine roots found during the growing season between the three- to four-leaf stage and veraison in both years, there was no other clear evidence of a change in fine root biomass to confirm that a fall flush of root growth occurred. However, a significant decrease in fine root biomass was found after harvest (Fig. 2), which implies that roots do not grow during the dormant season. Hence, root growth, as well as nutrient acquisition and competency in the study, was inferred from nutrient contents in fine roots and coarse roots, according to Volder et al. (2005), who found that the decline in $\mathrm{N}$ uptake and root respiration corresponded with a strong decline in root $\mathrm{N}$ concentration.

As shown in Figs. 4B, 5B, and 6B, respectively, seasonal changes of $\mathrm{N}, \mathrm{P}$, and $\mathrm{K}$ content found in various actively 


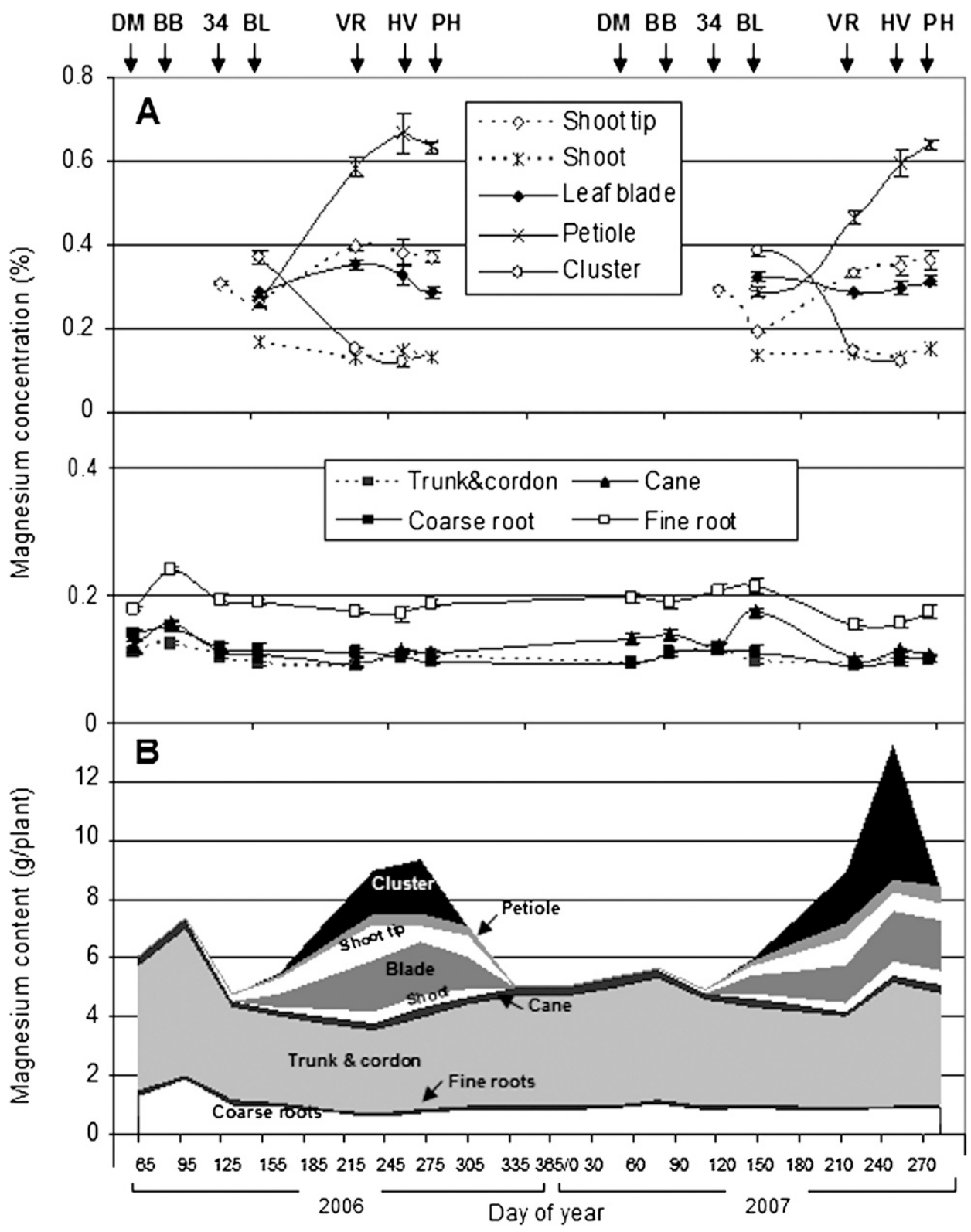

Fig. 8. Seasonal change in concentrations $(\mathbf{A})$ and contents $(\mathbf{B})$ of magnesium in various organs of 'Concord' grape destructively harvested in 2006 and 2007. Arrows at the top of graph indicate the time of dormant (DM), budbreak (BB), three- to four-leaf stage (34), bloom (BL), veraison (VR), harvest (HV), and postharvest (PH). SE are represented as bars above and below the mean.

growing organs showed similar trends in 2006 and 2007; the highest content in shoot tips occurred from bloom to veraison, and those in shoots, leaf blades, petioles, and clusters occurred at veraison. Nitrogen, $\mathrm{P}$, and $\mathrm{K}$ contents in coarse roots were lowest from veraison to harvest. In fine roots, $\mathrm{N}$ and $\mathrm{K}$ contents were very similar from winter to bloom and sharply declined at veraison and later growth stages, whereas $\mathrm{P}$ content showed no significant difference throughout the season. Hence, the nutrient decline in roots suggests translocation out of the roots and competition for nutrients between roots, canopy, and fruit. On the other hand, the highest contents of $\mathrm{Ca}$ and $\mathrm{Mg}$ in shoots, shoot tips, and leaf blades occurred from veraison to postharvest, which corresponds to the period of lowest contents in coarse and fine roots.
SoIL NUTRIENTS. Nutrient availabilities in soil did not show clear seasonal trends. With the exception of $\mathrm{NO}_{3}-\mathrm{N}$, significant differences were found between availability of all nutrients at surface and subsurface soils throughout and between each growing season. In both growing seasons, most nutrient concentrations in surface soil were higher than subsurface soil, except $\mathrm{Ca}$ and $\mathrm{Mg}$. The reason high concentrations of $\mathrm{Ca}$ and $\mathrm{Mg}$ were found in subsurface soil is likely due to calcification and weathering of basalt parent materials. There was no discernable relationship between soil and vine nutrient concentrations (data not given).

\section{Conclusions}

Dry weights of the whole vines ranged from 4229 to $9068 \mathrm{~g}$. The highest biomass of the whole plants occurred at harvest, which was about double of that in winter, budbreak, the three- to four-leaf stage, and bloom. Ca was the most abundant mineral nutrient in the vines, followed by $\mathrm{N}$ and $\mathrm{K}$. Between veraison and harvest, different tissues accounted for the majority of changes in $\mathrm{Ca}, \mathrm{N}$, and $\mathrm{K}$ contents. Half of the Ca was in woody tissues, up to $65 \%$ of $\mathrm{N}$ content was in annual tissues, and up to $70 \%$ of $\mathrm{K}$ was in the clusters. The high accumulation of $\mathrm{Ca}$ in vine permanent structures reflects high $\mathrm{Ca}$ in the vineyard soil.

Throughout the growing season, major changes of $\mathrm{P}$ content occurred in the cluster, whereas the major changes of $\mathrm{Mg}$ occurred in leaves and clusters. Most of the uptake of $\mathrm{N}, \mathrm{K}$, and $\mathrm{Ca}$ from the soil occurred between bloom and harvest in both years, whereas the highest $\mathrm{P}$ and $\mathrm{Mg}$ uptake per vine occurred from bloom to veraison in 2006 and between veraison and harvest in 2007. Withdrawal of N, P, and K from leaf blades, shoot tips, and petioles to woody tissues occurred between veraison and leaf senescence with no additional nutrient uptake, whereas neither $\mathrm{Mg}$ nor $\mathrm{Ca}$ were withdrawn to woody tissues.

The majority of $\mathrm{N}$ uptake that occurred at veraison and continued through harvest was largely driven by the large canopy and high crop load. In addition, there were sufficient $\mathrm{N}$ reserves in the woody tissues for the mature vines to use for growth in the early season. In addition, the long period of fruit ripening and short postharvest period in this cool climate facilitated a prolonged uptake period and rapid nutrient remobilization back to woody tissues during active vine growth. 
Table 3. Seasonal uptake of nutrients in 2006 and 2007 calculated from the change in total 'Concord' grape vine content of each nutrient between growth stages $(n=4)$.

\begin{tabular}{|c|c|c|c|c|c|}
\hline \multirow[b]{2}{*}{ Nutrient } & \multirow{2}{*}{$\begin{array}{l}\text { Avg total uptake } \\
\text { (g/plant) }\end{array}$} & \multicolumn{3}{|c|}{ Vine uptake (\% of total) } & \multirow{2}{*}{$\begin{array}{l}\text { Significance by } \\
\text { growth stage }(P)\end{array}$} \\
\hline & & Before bloom & Bloom to veraison & Veraison to harvest & \\
\hline \multicolumn{6}{|l|}{2006} \\
\hline $\mathrm{N}$ & 21.2 & $7 b^{z}$ & $45 \mathrm{a}$ & $48 \mathrm{a}$ & 0.057 \\
\hline K & 45.2 & $11 \mathrm{~b}$ & $69 a$ & $20 \mathrm{~b}$ & 0.043 \\
\hline $\mathrm{Ca}$ & 18.2 & $0 \mathrm{~b}$ & $63 \mathrm{a}$ & $37 \mathrm{ab}$ & 0.030 \\
\hline $\mathrm{Mg}$ & 3.3 & $0 \mathrm{~b}$ & $91 \mathrm{a}$ & $9 \mathrm{~b}$ & 0.032 \\
\hline $\mathrm{N}$ & 32.6 & $10 \mathrm{~b}$ & $28 \mathrm{~b}$ & $62 \mathrm{a}$ & 0.002 \\
\hline $\mathrm{P}$ & 8.5 & $13 \mathrm{~b}$ & $35 \mathrm{ab}$ & $52 \mathrm{a}$ & 0.061 \\
\hline K & 65.5 & $9 \mathrm{c}$ & $58 \mathrm{a}$ & $33 \mathrm{~b}$ & 0.002 \\
\hline $\mathrm{Ca}$ & 44.2 & $15 \mathrm{~b}$ & $36 \mathrm{a}$ & $49 \mathrm{a}$ & 0.003 \\
\hline $\mathrm{Mg}$ & 7.9 & $8 \mathrm{~b}$ & $39 a$ & $52 \mathrm{a}$ & 0.001 \\
\hline
\end{tabular}

${ }^{\mathrm{z}}$ Results within a column are significantly different (LSD at $P<0.05$ ) when letters following the value differ.

\section{Literature Cited}

Aegerter, A.F. and R.J. Folwell. 1996. 'Concord' grape establishment and production costs in Washington. Washington State Univ. Coop. Ext. Bul. 1823E.

Alexander, D.M.E. 1958. Seasonal fluctuation in the nitrogen content of the Sultana vine. Aust. J. Agr. Res. 8:162-178.

Araujo, F.J. and L.E. Williams. 1988. Dry matter and nitrogen partitioning and root growth of young field-grown Thomson Seedless grapevines. Vitis 27:21-32.

Barber, S.A. 1984. Soil nutrient bioavailability: A mechanistic approach. Wiley, New York.

Bates, T.R., R.M. Dunst, and P. Joy. 2002. Seasonal dry matter, starch and nutrient distribution in 'Concord' grapevine roots. HortScience 37:313-316.

Borchert, R. 1976. The concept of juvenility in woody plants. Acta Hort. 56:21-33.

Colugnati, G., A. Boschin, F. Bregant, S. Tagliavini, and M. Montanari. 1997. Preliminary results concerning the effects of a new fertilizer for grape nutrition. Acta Hort. 448:403-410.

Conradie, W.J. 1980. Seasonal uptake of nutrients by Chenin Blanc in sand culture: I. Nitrogen. South African J. Enol. Viticult. 1:59-65.

Conradie, W.J. 1981. Seasonal uptake of nutrients by Chenin Blanc in sand culture: II. Phosphorus, potassium, calcium and magnesium. South African J. Enol. Viticult. 2:7-13.

Conradie, W.J. 1986. Utilization of nitrogen by the grapevine as affected by time of application and soil type. South African J. Enol. Viticult. 4:91-98.

Conradie, W.J. 1992. Partitioning of nitrogen by the grapevine during autumn and the utilization of nitrogen reserves during the following growing season. South African J. Enol. Viticult. 13:45-51.

Conradie, W.J. 2005. Partitioning of mineral nutrients and timing of fertilizer application for optimum efficiency. Proc. Symp. Soil Environment and Vine Mineral Nutrition. Amer. Soc. Enol. Viticult., Davis, CA. p. 69-81.

Dahnke, W.C. 1990. Testing soils for available nitrogen, p. 120-140. In: R.L. Westerman (ed.). Soil testing and plant analysis. Soil Sci. Soc. Amer. Book Ser. 3, Amer. Soc. Agron., Madison, WI.

Demarty, M., C. Morvan, and M. Thellier. 1984. Calcium and the cell wall. Plant Cell Environ. 7:441-448.

Epstein, E. and A.J. Bloom. 2005. Mineral nutrition of plants: Principles and perspectives. 2nd ed. Sinauer, Sunderland, MA.

Hanson, E.J. and G.S. Howell. 1995. Nitrogen accumulation and fertilizer use efficiency by grapevines in short-season growing areas. HortScience 30:504-507.

Kinzel, H. 1989. Calcium in the vacuoles and cell walls of plant tissue. Flora 182:99-125.
Löhnertz, O. 1991. Soil nitrogen and the uptake of nitrogen in grapevines. Proc. Intl. Symp. Nitrogen in Grapes and Wine. Amer. Soc. Enol. Viticult., Davis, CA. p. 1-11.

Marschner, H. 2002. Mineral nutrition of higher plants, 2nd ed. Academic Press, London.

Mehlich, A. 1984. Mehlich-3 soil test extractant: A modification of Mehlich-2 extractant. Commun. Soil Sci. Plant Anal. 15:1409-1416.

Mullins, M.G., A. Bouquet, and L.E. Williams. 1992. Biology of the grapevine. Cambridge University Press, Cambridge, UK.

Robinson, J.B. 2005. Critical plant tissue values and application of nutritional standards for practical use in vineyards. Proc. Symp. Soil Environment and Vine Mineral Nutrition. Amer. Soc. Enol. Viticult., Davis, CA. p. 61-68.

Rogiers, S.Y., D.H. Greer, J.M. Hatfield, B.A. Orchard, and M. Keller. 2006. Mineral sinks within ripening grape berries (Vitis vinifera L.). Vitis 45:115-123.

Schaller, K., O. Löhnertz, and V. Chikkasubbanna. 1992. Uptake of potassium by the grape berries of different cultivars during growth and development. Viticult. Enol. Sci. 47:36-39.

Schreiner, R.P., C.F. Scagel, and J. Baham. 2006. Nutrient uptake and distribution in a mature 'Pinot Noir' vineyard. HortScience 41:336345.

Soltanpour, P.N., G.W. Johnson, S.M. Workman, J.B. Jones, Jr., and R.O. Miller. 1996. Inductively coupled plasma emission spectrometry and inductively coupled plasma-mass spectrometry, p. 91-139. In: D.L. Sparks (ed.). Methods of soil analysis. Part 3. Soil Sci. Soc. Amer., Madison, WI.

Tagliavini, M., C. Xavalloni, A.D. Rombola, M. Quartieri, D. Malaguti, F. Mazzanti, P. Millard, and B. Marangoni. 2000. Mineral nutrient partitioning to fruits of deciduous tree. Acta Hort. 512:131140.

U.S. Department of Agriculture. 2008. Non-citrus fruits and nuts 2007 preliminary summary. 23 Jan. 2008. <http://usda.mannlib.cornell. edu/usda/current/NoncFruiNu/NoncFruiNu-01-23-2008.pdf/>.

Volder, A., D.R. Smart, A.J. Bloom, and D.M. Eissenstat. 2005. Rapid decline in nitrate uptake and respiration with age in fine lateral roots of grape: Implications for root efficiency and competitive effectiveness. New Phytol. 165:493-502.

Wermelinger, B. 1991. Nitrogen dynamics in grapevine: Physiology and modeling. Intl. Symp. Nitrogen in Grapes and Wine. Amer. Soc. Enol. Viticult., Davis, CA. p. 23-30.

Williams, L.E. and P.J. Biscay. 1991. Partitioning of dry weight, nitrogen, and potassium in Cabernet Sauvignon grapevines from anthesis until harvest. Amer. J. Enol. Viticult. 42:113-117.

Yeomans, J.C. and J.M. Bremner. 1991. Carbon and nitrogen analysis of soils by automated combustion techniques. Commun. Soil Sci. Plant Anal. 22:843-850. 